\title{
Pemanfaatan dan Skrining Fitokimia Infusa Daun Rumput Knop (Hyptis capitata Jacq.)
}

\section{Utilization and Phytochemicals Screening of Knobweed (Hyptis capitata Jacq.) Leaves Infusion}

\author{
Nelsiani To'bungan \\ Prodi Biologi, Fakultas Teknobiologi, Universitas Atma Jaya Yogyakarta \\ Jl. Babarsari No. 44, Depok, Sleman, D.I. Yogyakarta, Indonesia \\ Email: nelsiani.tobungan@uajy.ac.id.
}

\begin{abstract}
Knobweed (Hyptis capitata Jacq.) is widely used as traditional medicine by the Torajanese. Scientific information about the use of knobweed and the content of secondary metabolites that are efficacious as traditional medicine is still limited. This research was conducted to gather information from the Torajanese about the efficacy of knobweed to overcome various diseases, variations in plant organs that are used as medicine and how to process them. Knobweed utilization data obtained through interviews. To support the efficacy data, qualitative phytochemical tests include alkaloid, triterpenoid, steroid, saponin, tannin and flavonoid tests. Knobweed is applied for several diseases such as stomach ache, headache, fever and open wounds. Plant organs that are often used in medicine are young leaves. The most common method of processing is boiling. Based on these results, the organs chosen for phytochemical screening are the leaves and the secondary metabolite extraction method using the infusion method. Phytochemical screening shows that Knobweed infusion contains steroids, tannins and flavonoids.
\end{abstract}

Keywords: Ethnobotany, Infusion, Knopweed, Nutraseutical, Phytochemicals

\begin{abstract}
Abstrak
Rumput Knop (Hyptis capitata Jacq.) banyak dimanfaatkan sebagai obat tradisional oleh masyarakat suku Toraja. Rumput knop berpotensi sebagai obat tradisional, namun informasi ilmiah tentang pemanfaatan Rumput Knop dan kandungan metabolit sekundernya masih terbatas. Oleh karena itu, penelitian ini dilakukan untuk mengumpulkan informasi dari masyarakat suku Toraja mengenai khasiat Rumput Knop dalam mengatasi berbagai penyakit, variasi organ tumbuhan yang dimanfaatkan sebagai obat dan cara pengolahannya. Data pemanfaatan rumput knop diperoleh melalui wawancara. Untuk mendukung data khasiat, dilakukan uji fitokimia kualitatif meliputi uji alkaloid, triterpenoid, steroid, saponin, tannin dan flavonoid. Rumput knop diaplikasikan untuk beberapa penyakit seperti sakit perut, sakit kepala, demam dan luka terbuka. Organ tumbuhan yang sering digunakan dalam pengobatan adalah daun muda. Cara pengolahan yang paling banyak dilakukan adalah perebusan. Berdasarkan hasil tersebut, maka organ yang dipilih untuk dilakukan skrining fitokimia adalah daun dan metode ekstraksi metabolit sekundernya dengan metode infusa. Skrining fitokimia menunjukkan infusa daun Rumput Knop mengandung flavonoid, steroid dan tannin.
\end{abstract}

Kata Kunci: Etnobotani, Infusa, Rumput Knop, Nutrasetika, Fitokimia

Diterima: 23 April 2020, disetujui: 16 Agustus 2020

\section{Pendahuluan}

Salah satu kearifan lokal yang saat ini masih dijumpai di Indonesia adalah pemanfaatan tumbuhan sebagai obat tradisional. Pengetahuan tentang khasiat tumbuhan tertentu dalam mengatasi berbagai penyakit, diwariskan secara turun temurun. Pengetahuan tersebut membudaya pada masing-masing suku dan daerah, sehingga masing-masing suku dan daerah tersebut 
memiliki metode pengobatan tradisional yang khas.

Suku Toraja sampai saat ini, tetap mempertahankan budaya penggunaan tumbuhan sebagai obat. Salah satu tumbuhan yang banyak dimanfaatkan sebagai obat adalah Rumput Knop (Hyptis capitata Jacq.) (Yohana et al., 2015). Rumput Knop (Gambar 1.) adalah tumbuhan herba yang sering kali dianggap sebagai gulma (Ngatiman \& Nurcahyono, 2016). Tumbuhan ini dapat tumbuh hingga mencapai dua meter (Datar et $a l .$, 2007).

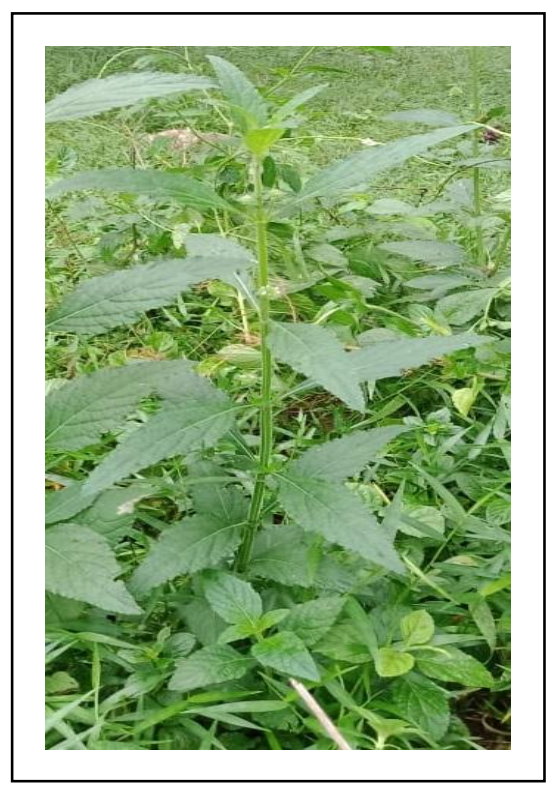

Gambar 1. Rumput Knop (Hyptis capitata Jacq.) (Dokumentasi Pribadi, 2019)

Informasi ilmiah mengenai pemanfaatan rumput Knop (Hyptis capitata Jacq.) sebagai obat tradisional oleh masyarakat masih sangat terbatas. Informasi tersebut penting untuk dijadikan dasar pengkajian lebih lanjut potansi rumput Knop (Hyptis capitata Jacq.) sebagai kandidat bahan obat. Dalam penelitian ini dikaji beberapa informasi mengenai organ rumput Knop (Hyptis capitata Jacq.) yang dimanfaatkan sebagai obat, khasiat yang dipercaya oleh masyarakat serta cara pengolahannya. Dilakukan pula skrining fitokimia, untuk mengetahui kandungan senyawa yang berperan penting dalam penyembuhan penyakit.

\section{Metode Penelitian}

\section{Wawancara}

Data khasiat, organ tumbuhan yang dimanfaatkan dan cara pengolahannya diperoleh dengan cara wawancara terhadap 5 orang suku Toraja, yg masing-masing menempati 5 dusun yang berbeda di desa Bungapati, Luwu Utara, Sulawesi Selatan.

\section{Pembuatan Infusa}

Infusa dibuat berdasarkan acuan sediaan herbal Badan Pengawas Obat dan Makanan, dengan memanaskan 8 gram daun Rumput Knop (Hyptis capitata Jacq.) yang telah dirajang halus dengan air pada suhu $90^{\circ} \mathrm{C}$ selama 15 menit (BPOM, 2012)

\section{Skrining Fitokimia}

Skrining fitokimia dilakukan di Laboratorium Teknobioindustri, Fakultas Teknobiologi, Universitas Atma Jaya Yogyakarta. Skrining fitokimia yang dilakukan meliputi uji alkaloid, terpenoid/steroid, saponin, tannin dan flavonoid. Adapun metode untuk masing-masing uji fitokimia adalah sebagai berikut.

1. Uji Alkaloid

Uji Alkaloid dilakukan dengan 3 metode, yaitu metode Meyer, Wagner dan Dragendorf. Sampel direaksikan dengan kloroform sebanyak $5 \mathrm{ml}$ dan amoniak 5 $\mathrm{ml}$, lalu dipanaskan, dikocok dan disaring. Ditambahkan dengan 5 tetes asam sulfat 
$2 \mathrm{~N}$ pada masing-masing filtrat, lalu kocok dan didiamkan. Lapisan atas dari masing-masing filtrat diambil dan diuji dengan pereaksi Meyer, Wagner, dan Dragendorf. Hasil positif alkaloid, ditunjukkan dengan terbentuknya endapan jingga, cokelat, dan putih (Mondong et al., 2015)

2. Uji terpenoid/steroid

Sampel pertama dicampurkan dengan $2 \mathrm{ml}$ asam sulfat pekat $\left(\mathrm{H}_{2} \mathrm{SO}_{4}\right)$. Kandungan steroid ditunjukkan dengan terbentuknya warna hijau atau hijau biru. Sampel kedua ditambahkan dengan asam sulfat pekat serta anhidrida asetat. Terbentuknya warna merah atau merah ungu, menunjukkan positif terpenoid. (Rafiqi et al., 2017).

3. Uji Saponin

Sampel dengan berat 0,5 gram dimasukkan ke dalam tabung reaksi, yang sebelumnya telah diisi dengan $10 \mathrm{ml}$ akuades. Tabung kemudian dikocok, lalu ditambahkan 1 tetes larutan asam klorida 2 N. Selanjutnya, tabung reaksi didiamkan dan diperhatikan terbentuk tidaknya busa yang stabil. Hasil positif saponin, dicirikan dengan terbentuk busa yang stabil dengan ketinggian 1-3 cm selama 30 detik (Bintoro et al., 2017).

4. Uji Tanin

Sebanyak $\quad 0,1$ gram sampel dimasukkan ke tabung reaksi. Ditambahkan $10 \mathrm{ml}$ akuades. kemudian didiamkan 5 menit, lalu disaring. Hasil saringan didiamkan selama 5 menit, lalu ditambah dengan 5 tetes larutan $\mathrm{FeCl}_{3} \quad 1 \%$.

Terbentuknya warna biru ataupun hijau kehitaman menunjukkan positif tannin (Marlinda et al., 2012)

5. Uji Flavonoid

Sampel dengan konsentrasi 100 ppm dimasukkan sebanyak $1 \mathrm{ml}$ ke dalam tabung reaksi. Sampel dididihkan dengan $10 \mathrm{ml}$ air dalam penangas air, lalu ditambahkan $\mathrm{HCl}$ sebanyak $1 \mathrm{ml}$. Larutan tersebut ditambahkan dengan serbuk Magnesium (Mg) sebanyak $100 \mathrm{mg}$. Terbentuknya warna merah atau kuning atau jingga menunjukkan positif flavonoid (Noer et al., 2018)

\section{Hasil dan Pembahasan}

Rumput Knop (Hyptis capitata Jacq.)
dimanfaatkan masyarakat sebagai obat
tradisional untuk beberapa jenis gangguan
kesehatan. Organ Rumput Knop (Hyptis
capitata Jacq.) yang paling banyak
dimanfaatkan sebagai obat adalah daun muda.
Daun merupakan organ tumbuhan yang paling
banyak dimanfaatkan sebagai obat. Hal ini
merupakan upaya untuk tetap menjaga
kelestarian tumbuhan obat, karena
memanfaatkan daun, tidak langsung
mematikan tumbuhan (Mulyani et al., 2020).
Adapun cara pengolahan yang paling banyak
digunakan adalah dengan merebus. Hasil
wawancara dengan 5 orang responden tentang
pemanfaatan Rumput Knop (Hyptis capitata
Jacq.) untuk pengobatan dapat dilihat pada
Tabel 1.

Tabel 1. Pemanfaatan Rumput Knop (Hyptis capitata Jacq.) untuk Pengobatan

\begin{tabular}{ccccc}
\hline \hline No. & Pemanfaatan/Kegunaan & $\begin{array}{c}\text { Organ yang } \\
\text { Digunakan }\end{array}$ & Cara Pengolahan & Keterangan \\
\hline \hline 1. & Demam & Daun muda & $\begin{array}{c}\text { Direbus, sebagai rempah } \\
\text { digunakan saat mandi }\end{array}$ & $\begin{array}{c}\text { Informasi dari } \\
\text { semua responden }\end{array}$ \\
\hline 2. & Sakit Kepala & $\begin{array}{c}\text { Daun dan batang } \\
\text { muda }\end{array}$ & $\begin{array}{c}\text { Direbus, sebagai rempah } \\
\text { digunakan saat mandi }\end{array}$ & $\begin{array}{c}\text { Informasi dari } \\
\text { responden ke-2 }\end{array}$ \\
\hline 3. & Sakit Perut/Diare & $\begin{array}{c}\text { Pucuk, daun dan } \\
\text { batang muda }\end{array}$ & $\begin{array}{c}\text { Diseduh, direbus, } \\
\text { dimakan langsung }\end{array}$ & $\begin{array}{c}\text { Informasi dari } \\
\text { responden ke-1 }\end{array}$ \\
\hline 4. & Perut Kembung & Daun muda & Diseduh, untuk diminum & $\begin{array}{c}\text { Informasi dari } \\
\text { responden ke-3 dan } \\
\text { ke-4 }\end{array}$ \\
\hline 5. & Luka Terbuka & Daun muda & $\begin{array}{c}\text { Direbus, ditumbuk, } \\
\text { dibalurkan pada luka }\end{array}$ & $\begin{array}{c}\text { Informasi dari } \\
\text { semua responden }\end{array}$ \\
\hline \hline
\end{tabular}


Biota: Jurnal Ilmiah Ilmu-Ilmu Hayati, Vol. 5 (3): 149-154, Oktober 2020 p-ISSN 2527-3221, e-ISSN 2527-323X, https://ojs.uajy.ac.id/index.php/biota DOI: 10.24002/biota.v5i3.3520

Pada umumnya masyarakat mengolah daun Rumput Knop (Hyptis capitata Jacq.) dengan cara direbus, sebelum digunakan sebagai obat. Berdasarkan metode tersebut maka, dipilih metode ekstraksi yang mendekati metode rebus yaitu dengan infusa. Pembuatan infus adalah metode yang sederhana untuk membuat sediaan herbal yang berasal dari daun atau bunga (BPOM, 2012). Metode infusa berbeda dengan metode rebus, karena hanya menggunakan air bersuhu $90^{\circ} \mathrm{C}$. Metode perebusan tidak dipilih karena ekstraksi dengan merebus dapat mengubah, merusak ataupun menghilangkan senyawa bioaktif tertentu (Santoso et al., 2012; Puspitasari \& Desrita 2019). Hasil ekstraksi dengan metode infusa menghasilkan infusa yang berwarna coklat pekat (Gambar 2) dengan aroma khas Rumput Knop (Hyptis capitata Jacq.) yang kuat.

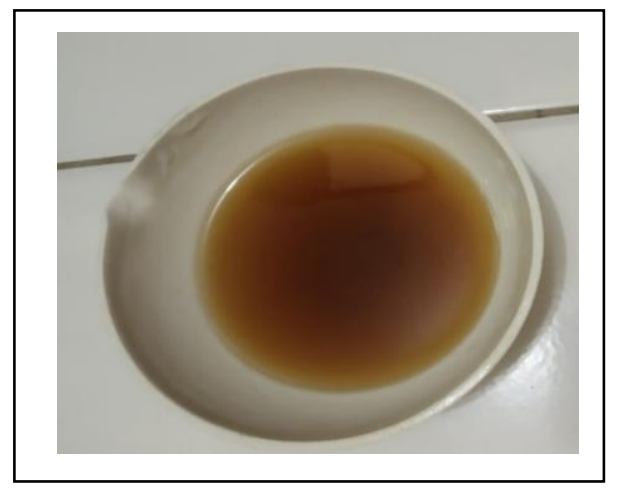

Gambar 2. Infusa Daun Rumput Knop

Skrining fitokimia terhadap infusa daun

Rumput Knop (Hyptis capitata Jacq.) dilakukan untuk mengetahui kandungan senyawa fitokimia yang berperan dalam penyembuhan berbagai gangguan kesehatan.
Hasil uji fitokimia infusa daun Rumput Knop (Hyptis capitata Jacq.) ditunjukkan pada Tabel 2. Infusa daun Rumput Knop terdeteksi mengandung steroid, tannin dan flavonoid.

Tabel 2. Skrining Fitokimia Infusa Daun Rumput Knop

\begin{tabular}{ll}
\hline \multicolumn{1}{c}{ Pengujian } & Hasil \\
\hline Alkaloid & \\
Mayer & - \\
Wagner & - \\
Dragendorf & - \\
\hline Terpenoid & - \\
\hline Steroid & + \\
\hline Saponin & - \\
\hline Tannin & + \\
\hline Flavonoid & + \\
\hline \hline
\end{tabular}

Keterangan: + : terdeteksi, - : tidak terdeteksi

Steroid, tannin, dan flavonoid merupakan senyawa metabolit sekunder yang bermanfaat dalam penyembuhan penyakit. Steroid dapat berpotensi sebagai antiinflamasi (Patel \& Savjani, 2015). Jika dikaitkan dengan pemanfaatan Rumput Knop sebagai obat luka terbuka, maka kandungan streroid pada daun yang berperan sebagai antiinflamasi, dapat mengurangi peradangan atau pembengkakan pada luka. Kandungan tannin pada Rumput Knop berkontribusi sebagai obat diare. Saat tannin bertemu dengan lapisan mukosa usus, 
tannin menyebabkan lapisan mukosa lebih rapat dan kurang permeable (Astrigency). Hal ini meningkatkan perlindungan pada permukaan usus dari mikroorganisme atau bahan kimia penyebab iritasi (Russo et al., 2018).

Tannin dan flavonoid memiliki potensi sebagai antioksidan (Benzidia et al., 2019; Hanin \& Pratiwi, 2017). Antioksidan alami dapat dijumpai pada seluruh bagian tumbuhan (Anuj et al., 2016). Antioksidan berperan untuk menghambat pembentukan, memulung ataupun menginduksi dekomposisi radikal bebas, sehingga kerusakan jaringan dapat dicegah (Young \& Woodside, 2001). Salah satu bentuk radikal bebas yang dapat dihambat pembentukannya oleh antioksidan adalah Reactive Oxigen Species (ROS). ROS juga berkontribusi dalam mempertahankan nyeri kronis. Adanya antioksidan dapat berfungsi sebagai analgesik yang efektif (Hacimuftuoglu et al., 2006). Kandungan flavonoid sebagai kandidat antioksidan pada Rumput Knop dapat berkontribusi sebagai analgesik atau pereda nyeri dan inflamasi pada sakit kepala, demam dan perut kembung. Selain berfungsi sebagai antioksidan, flavonoid juga berpotensi sebagai antikanker dan antidiabetes (Chahar et al., 2011; Al-Ishaq et al., 2019). Kajian terkait potensi Rumput Knop sebagai kandidat sumber antioksidan, antikanker ataupun antidiabetes masih perlu untuk dilakukan secara lebih mendalam.

\section{Simpulan}

Rumput Knop (Hyptis capitata Jacq.) dimanfaatkan untuk mengobati demam, sakit kepala, sakit perut/diare, perut kembung dan luka terbuka. Bagian yang digunakan adalah daun muda, batang muda dan pucuk. Cara pengolahan antara lain, direbus, diseduh, dimakan, diremas, ditumbuk dan digunakan sebagai rempah untuk mandi. Infusa daun Rumput Knop (Hyptis capitata Jacq.) mengandung steroid, tannin dan flavonoid. Diperlukan uji toksisitas untuk mengevaluasi kemungkinan ada tidaknya efek samping dari penggunaan Rumput Knop sebagai obat.

\section{Daftar Pustaka}

Al-Ishaq, R. K., Abotaleb, M., Kubatka, P., Kajo, K., \& Büsselberg, D. 2019. Flavonoids and their anti-diabetic effects: Cellular mechanisms and effects to improve blood sugar levels. Biomolecules, 9(9). https://doi.org/10.3390/biom9090430

Anuj, Y., Rewa, K., Ashwani, Y., J.P., M., Seweta, S., \& Shashi, P. 2016. Antioxidants and its functions in human body. Research in Environment and Life Sciences, 9(11), 13281331.

Benzidia, B., Barbouchi, M., Hammouch, H., Belahbib, N., Zouarhi, M., Erramli, H., Ait Daoud, N., Badrane, N., \& Hajjaji, N. 2019. Chemical composition and antioxidant activity of tannins extract from green rind of Aloe vera (L.) Burm. F. Journal of King Saud University - Science, 31(4), 1175-1181. https://doi.org/10.1016/j.jksus.2018.05.022

Bintoro, A., Ibrahim, A. M., \& Situmeang, B. 2017. Analisis dan Identifikasi Senyawa Saponin dari Daun Bidara (Zhizipus mauritania L.). Jurnal ITEKIMA, 2(1), 84-94.

BPOM. 2012. Acuan Sediaan Herbal. In BPOM (Vol. 7, Issue https://doi.org/10.1017/CBO9781107415324. 004

Chahar, M. K., Sharma, N., Dobhal, M. P., \& Joshi, Y. C. 2011. Flavonoids: A versatile source of anticancer drugs. Pharmacognosy Reviews, 5(9), 1-12. https://doi.org/10.4103/09737847.79093

Datar, M. N., Lakshminarasimhan, P., \& Rao, P. S. N. 2007. Hyptis capitata Jacq.(Lamiaceae)-a new record for northern Western Ghats. Indian J. Forest, 30(3), 355-356.

Hacimuftuoglu, Handy, A. \&, Goettl, C. R. \&, V.M. \& Lin, C. ., \& Stephens, R. L. 2006. Antioxidants attenuate multiple phases of formalin-induced nociceptive response in mice. Behavioural brain research. Behavioural Brain Research, 173(2), 211216. https://doi.org/10.16258/j.cnki.16745906.2006.01.022

Hanin, N. N. F., \& Pratiwi, R. 2017. Kandungan Fenolik, Flavonoid dan Aktivitas Antioksidan Ekstrak Daun Paku Laut (Acrostichum aureum L.) Fertil dan Steril di Kawasan 
Mangrove Kulon Progo, Yogyakarta. Journal of Tropical Biodiversity and Biotechnology, 2(2), 51. https://doi.org/10.22146/jtbb.29819

Marlinda, M., Sangi, M. S., \& Wuntu, A. D. 2012. Analisis Senyawa Metabolit Sekunder dan Uji Toksisitas Ekstrak Etanol Biji Buah Alpukat (Persea americana Mill.). Jurnal MIPA, $\quad 1(1), \quad 24$. https://doi.org/10.35799/jm.1.1.2012.427

Mondong, F. R., Sangi, M. S., Kumaunang, M., \& Herb, L. 2015. Skrining Fitokimia dan Uji Aktivitas Antioksidan Ekstrak Etanol Daun Patikan Emas ( Euprorbia prunifolia Jacq .) dan Bawang Laut ( Proiphys amboinensis ( $L$ .) Herb ). 4(1), 81-87.

Mulyani, Y., Sumarna, R., \& Patonah. 2020. Kajian Etnofarmakologi, Pemanfaatan Tanaman Obat Oleh Masyarakat Di Kecamatan Dawuan Kabupaten Subang Provinsi Jawa Barat. Jurnal Farmasi Galenika (Galenika Journal of Pharmacy) (E-Journal), 6(1), 3754. https://doi.org/10.22487/j24428744.2020.v6.i 1.14106

Ngatiman, \& Nurcahyono, D. D. 2016. Identifikasi gulma pada tegakan. JURNAL Penelitian Ekosistem Dipterokarpa, 1.

Noer, S., Pratiwi, R. D., Gresinta, E., Biologi, P., \& Teknik, F. 2018. Penetapan Kadar Senyawa Fitokimia (Tanin, Saponin dan Flavonoid sebagai Kuersetin) Pada Ekstrak Daun Inggu (Ruta angustifolia L.). Eksata: Jurnal IlmuIlmu MIPA, 18(1), 19-29.
Patel, S. S., \& Savjani, J. K. 2015. Systematic review of plant steroids as potential antiinflammatory agents: Current status and future perspectives. The Journal of Phytopharmacology JPHYTO, 4(42), 121125. www.phytopharmajournal.com

Puspitasari, D., \& Desrita. 2019. Acta Aquatica. Acta Aquatica, 6(1), 28-31. https://doi.org/10.29103/aa.v1i1.299

Rafiqi, R., Arifin, B., \& Hasnirwan. 2017. Aktivitas Antioksidan dan Kandungan Fenolik Total Berbagai Fraksi dari Ekstrak Metanol Daun Melinjo (Gnetum gnemon L.). 6(4), 27-32.

Russo, M., Coppola, V., Giannetti, E., Buonavolontà, R., Piscitelli, A., \& Staiano, A. 2018. Oral administration of tannins and flavonoids in children with acute diarrhea: A pilot, randomized, control-case study. Italian Journal of Pediatrics, 44(1), 4-9. https://doi.org/10.1186/s13052-018-0497-6

Pasorong, Y.S., Tambaru, E., Umar, M.R. and Masniawati, A. 2015. Identifikasi Tumbuhan Berkhasiat Obat dan Potensi Pemanfaatannya pada Beberapa Desa di sekitar Gunung Sesean Kabupaten Tana Toraja. Fakultas Matematika dan Ilmu Pengetahuan Alam. Universitas Hasanuddin Makassar.

Young, I. S., \& Woodside, J. V. 2001. Antioxidants in health and disease. Journal of Clinical Pathology, 54(3), 176-186. https://doi.org/10.1136/jcp.54.3.176. 